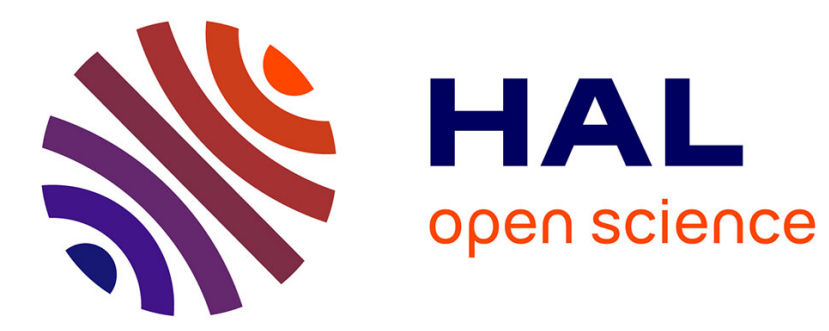

\title{
Removal of algal blooms from freshwater by the coagulation-magnetic separation method
}

Dan Liu, Pengbo Wang, Guanran Wei, Wenbo Dong, Franck Hui

\section{To cite this version:}

Dan Liu, Pengbo Wang, Guanran Wei, Wenbo Dong, Franck Hui. Removal of algal blooms from freshwater by the coagulation-magnetic separation method. Environmental Science and Pollution Research, 2013, 20 (1), pp.60-65. 10.1007/s11356-012-1052-4 . hal-02350710

\section{HAL Id: hal-02350710 https://hal.science/hal-02350710}

Submitted on 6 Nov 2019

HAL is a multi-disciplinary open access archive for the deposit and dissemination of scientific research documents, whether they are published or not. The documents may come from teaching and research institutions in France or abroad, or from public or private research centers.
L'archive ouverte pluridisciplinaire HAL, est destinée au dépôt et à la diffusion de documents scientifiques de niveau recherche, publiés ou non, émanant des établissements d'enseignement et de recherche français ou étrangers, des laboratoires publics ou privés. 


\title{
Removal of algal blooms from freshwater by the coagulation-magnetic separation method
}

\author{
Dan Liu • Peng Wang • Guanran Wei • Wenbo Dong • \\ Franck Hui
}

\begin{abstract}
This research investigated the feasibility of changing waste into useful materials for water treatment and proposed a coagulation-magnetic separation technique. This technique was rapid and highly effective for clearing up harmful algal blooms in freshwater and mitigating lake eutrophication. A magnetic coagulant was synthesized by compounding acid-modified fly ash with magnetite $\left(\mathrm{Fe}_{3} \mathrm{O}_{4}\right)$. Its removal effects on algal cells and dissolved organics in water were studied. After mixing, coagulation, and magnetic separation, the flocs obtained from the magnet surface were examined by SEM. Treated samples were withdrawn for the content determination of chlorophyll- $a$, turbidity, chemical oxygen demand (COD), total nitrogen, and total phosphorus. More than $99 \%$ of algal cells were removed within $5 \mathrm{~min}$ after the addition of magnetic coagulant at optimal loadings $\left(200 \mathrm{mg} \mathrm{L}^{-1}\right)$. The removal efficiencies of COD, total nitrogen, and phosphorus were 93, 91, and $94 \%$, respectively. The mechanism of algal removal explored preliminarily showed that the magnetic coagulant played multiple roles in mesoporous adsorption,
\end{abstract}

Responsible editor: Philippe Garrigues

D. Liu $(\varangle) \cdot$ P. Wang $\cdot$ W. Dong $(\square)$

Department of Environmental Science and Engineering,

Fudan University,

Shanghai 200433, China

e-mail: dliu1982@hotmail.com

e-mail: wbdong@fudan.edu.cn

F. Hui

Laboratoire Procédés et Ingénierie en Mécanique et Matériaux, Arts et Métiers ParisTech,

Paris 75013, France

G. Wei

School of Environmental Science and Engineering, Shanghai Jiao

Tong University,

Shanghai 200240, China netting and bridging, as well as high magnetic responsiveness to a magnetic field. The magnetic-coagulation separation method can rapidly and effectively remove algae from water bodies and greatly mitigate eutrophication of freshwater using a new magnetic coagulant. The method has good performance, is low cost, can turn waste into something valuable, and provides reference and directions for future pilot and production scale-ups.

Keywords Algal bloom · Coagulant · Magnetic separation · Adsorption · Coagulation

\section{Introduction}

The frequent outbreaks of algal blooms in freshwater bodies are a global issue (Anderson 1997; Beth 1998; Mackenzie 1999; Rigby 2000; Ruiz et al. 2000; Vasconcelos and Pereira 2001). Algal blooms seriously damage the balance and stability of aquatic ecosystems, which negatively affect the water landscape and aquaculture development. Blooms involving toxin-producing species can pose serious threats to animals and humans (Hoehn et al. 1990; Pouria et al. 1998; Codd 2000). Recent studies use physical, chemical, and ecological methods to control algal blooms to some extent (Lam et al. 1995; Anderson 1997; Datta and Jana 1998; Hejzlar et al. 1998; Nagasaki et al. 1999; Gao et al. 2010), but all have defects and limitations.

A recently proposed chemical method that uses natural, nontoxic, and inexpensive clay coagulant is gaining global popularity (Anderson 1997; Pierce et al. 2004; Sengco and Anderson 2004). The limitations of this method include large consumption of clay that causes excessive sediment siltation and considerable dredging work. When algae are moved underwater by the clay coagulant, algae are not prevented 
Table 1 Chemical composition of fly ash (mass fraction, in percent)

\begin{tabular}{lllllll}
\hline $\mathrm{SiO}_{2}$ & $\mathrm{Al}_{2} \mathrm{O}_{3}$ & $\mathrm{Fe}_{2} \mathrm{O}_{3}$ & $\mathrm{CaO}$ & $\mathrm{MgO}$ & $\mathrm{SO}_{3}$ & $\begin{array}{l}\text { Loss on } \\
\text { ignition }\end{array}$ \\
\hline $49 \sim 52$ & $30 \sim 38$ & $5 \sim 12$ & $3 \sim 6$ & $<1$ & $<1$ & $1 \sim 5$ \\
\hline
\end{tabular}

from floating in shallow rivers and lakes. Secondary pollution caused by toxic substances (e.g., algal toxins) released from decomposition also ensues. Nitrogen $(\mathrm{N})$, phosphorus $(\mathrm{P})$, and potassium $(\mathrm{K})$ released from algal decay will return to the water body. Consequently, the root cause of eutrophication is not solved completely and blooms will continue to relapse (Pan et al. 2006; Zou et al. 2006).

Fly ash is a major waste of thermal power plants. China relies heavily on coal-fired plants for power, and approximately 1 billion tons of fly ash emissions is produced annually. However, the current utilization rate mainly of the construction, transportation, and soil improvement industries is only $40 \%$. The unused emissions are either stored in gray fields or discharged to rivers and lakes, resulting in land consumption and serious environmental issues. Thus, fly ash utilization has become a very important research topic (Pengthamkeerati et al. 2008).

The current paper proposes a method of modifying fly ash into a magnetic coagulant by a simple, low-cost process that uses waste to treat water. The advanced technology of magnetic coagulation separation is used to remove algae from a water body rapidly. $\mathrm{N}$ and $\mathrm{P}$ are also efficiently removed. Thus, this method can tackle the problem of algal blooms and mitigate the eutrophication of freshwater.

\section{Materials and methods}

\section{Materials}

A magnetic coagulant (a new selective water treatment agent in the form of black powder) was prepared from acid-modified fly ash compounded with magnetite according to a specific proportion $\left(m_{\text {flyash }} / m_{\text {magnetite }} /\right.$ $V_{\mathrm{HCl}}=2 \mathrm{~g}: 1 \mathrm{~g}: 1 \mathrm{~mL}$ ). Fly ash was obtained from Hefei
Power Plant, and its main chemical components are listed in Table 1. Magnetite $\left(\mathrm{Fe}_{3} \mathrm{O}_{4}\right.$; red and black amorphous powder, chemical grade) was provided by Sinopharm Chemical Reagent Co. Ltd. The other reagents used were analytical grade.

Algal suspensions were collected from the Chaohu Lake (Hefei, China) when algal blooms occurred and then configured with deionized water as controls $\left(A_{680} \mathrm{~nm}=0.15, \mathrm{pH} 7.0\right)$. The water quality data are shown in Table 2. The absorbance of the water samples was measured with a TU-1901 double-beam UV-Vis spectrophotometer (Shimadzu).

\section{Experimental procedure}

The experimental procedure is summarized in Fig. 1. About $500 \mathrm{~mL}$ of algal suspension was placed in an $800-\mathrm{mL}$ beaker and stirred at a speed of $300 \mathrm{rpm}$. Magnetic coagulants were added under stirring. After stirring for $1 \mathrm{~min}$, the speed was adjusted to $60 \mathrm{rpm}$ for $3 \mathrm{~min}$. A permanent magnet $(0.5 \mathrm{~T})$ was then used to separate magnetic flocs to be examined with SEM. Samples $5 \mathrm{~cm}$ below the liquid level were collected and used to determine the contents of chlorophyll- $a$ (Chl- $a$ ), turbidity, chemical oxygen demand (COD), total $\mathrm{N}$, and total P.

Analytical methods

For SEM observation, some magnetic floc samples were placed on a microporous membrane with a $0.45-\mu \mathrm{m}$ aperture. The samples were solidified with $2.5 \%$ glutaraldehyde solution $(2.5 \%)$ for $1 \mathrm{~h}$ and rinsed with phosphate buffer. A 50-100 \% ethanol gradient was used to dehydrate the samples. They were then dried at the critical point and vacuum sprayed with gold. They were observed and photographed using a KYKY1010B scanning electron microscope (Liu et al. 2009).

For Chl- $a$ measurement, $20 \mathrm{~mL}$ of the test solution was filtered through a $0.45-\mu \mathrm{m}$ microporous membrane. The membrane was dissolved completely in $8 \mathrm{~mL}$ of $90 \%$ acetone solution and centrifuged at a speed of $3,500 \mathrm{rpm}$ for $10 \mathrm{~min}$. The supernatant was collected to determine the absorbance at 750,663, 645, and $630 \mathrm{~nm}$.
Table 2 Effect of $200 \mathrm{mg} \mathrm{L}^{-1}$ magnetic coagulants on water quality of algal suspension

\begin{tabular}{llllll}
\hline Parameters & $\begin{array}{l}\text { Chlorophyll- } a \\
\left(\mu \mathrm{g} \mathrm{L}^{-1}\right)\end{array}$ & $\begin{array}{l}\text { Turbidity } \\
(\mathrm{NTU})\end{array}$ & $\begin{array}{l}\mathrm{COD} \\
\left(\mathrm{mg} \mathrm{L}^{-1}\right)\end{array}$ & $\begin{array}{l}\text { Total nitrogen } \\
\left(\mathrm{mg} \mathrm{L}^{-1}\right)\end{array}$ & $\begin{array}{l}\text { Total phosphorus } \\
\left(\mathrm{mg} \mathrm{L}^{-1}\right)\end{array}$ \\
\hline Before treatment & 176.7 & 130 & 131.75 & 6.2 & 1.37 \\
After treatment & - & 0.5 & 9.14 & 0.55 & 0.08 \\
Removal efficiency (\%) & 100 & 99.6 & 93 & 91 & 94 \\
\hline
\end{tabular}


Fig. 1 Experimental flow chart of algal treatment

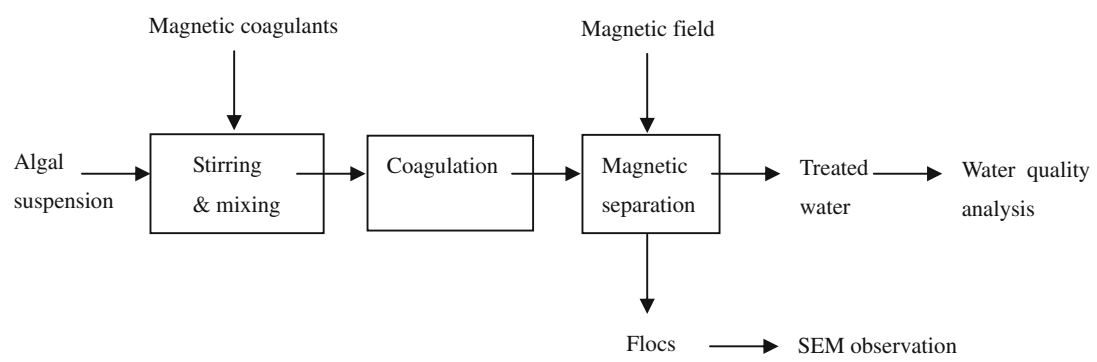

The absorbance values were converted to the Chl- $a$ content by the following formula (Yu et al. 1990):

$\mathrm{Chl}-a\left(\mu \mathrm{g} \mathrm{L}^{-1}\right)=\left[11.64 \cdot\left(A_{663 \mathrm{~nm}}-A_{750 \mathrm{~nm}}\right)-2.16 \cdot\left(A_{645} \mathrm{~nm}-A_{750 \mathrm{~nm}}\right)+0.10 \cdot\left(A_{630 \mathrm{~nm}}-A_{750 \mathrm{~nm}}\right)\right] \cdot 400$.

The turbidity was determined by spectrophotometry and the COD by the potassium dichromate method. The total $\mathrm{N}$ was determined by alkaline potassium persulfate digestionUV spectrophotometry and the total $\mathrm{P}$ by the ammonium molybdate spectrophotometry (State Environmental Protection Administration of China 2002).

\section{Results and discussion}

Determination of optimum dosage of magnetic coagulants

Figure 2 shows that the turbidity removal rate for the algal suspension increases with increased magnetic coagulant dosage. The rate decreases when the dosage exceeds a particular threshold, and $200 \mathrm{mg} \mathrm{L}^{-1}$ is found to be the optimum threshold dosage. This phenomenon can be explained by the principle of coagulation. The functional groups of the coagulant form bridges and adsorb onto the particle surface to form thick flocs. With increased dosage, more molecules participate in the adsorption and bridging. Better colloidal cohesion results in higher turbidity removal rates. However, coagulant overdosage leads to adsorption saturation and overlay formation on every colloid, which produces a second stable phenomenon that decreases the turbidity removal rate (Zhang et al. 2010).

Effects of magnetic coagulants on algal suspensions

Figure 3 indicates that the magnetic coagulant has a very good purification effect, i.e., the UV-Visible light absorption significantly decreased compared with the original suspension (Figs. 4 and 5). Table 2 shows the water quality changes before and after adding the magnetic coagulants.

The Chl- $a$ content is an indicator of algal biomass, and the cell quantity is a major factor that causes turbidity. Thus, Chl- $a$ reduction or turbidity reduction can been considered as algal removal. (Divakaran and Pillai 2002). We used Chl$a$ and turbidity removal rates (100\% or almost $100 \%$ ) to prove that the magnetic coagulant is effective in reducing algal blooms. The treated suspension shows an increased COD removal rate, indicating that the magnetic coagulant can effectively reduce the organic matter level, whereas the decrease in organic matter causes UV-Visible light absorption reduction.

The major nutrients that cause blooms are $\mathrm{N}$ and $\mathrm{P}$, with $\mathrm{P}$ playing a key role. The magnetic coagulant shows obvious removal effect on $\mathrm{N}$ and especially on $\mathrm{P}$. Modified fly ash has chemical adsorption effects on $\mathrm{P}$, i.e., $\mathrm{Ca}^{2+}$ precipitation effects on $\mathrm{PO}_{4}{ }^{3-}, \mathrm{HPO}_{4}{ }^{2-}$, and $\mathrm{H}_{2} \mathrm{PO}_{4}{ }^{-}$. $\mathrm{CaO}$ reacts with water to generate a quantitative amount of $\mathrm{Ca}^{2+}$. Subsequently, $\mathrm{Ca}^{2+}$ and $\mathrm{PO}_{4}{ }^{3-}, \mathrm{HPO}_{4}{ }^{2-}$, or $\mathrm{H}_{2} \mathrm{PO}_{4}{ }^{-}$of various phosphates build a complex family of calcium phosphates such as amorphous calcium phosphate, calcium hydrogenphosphate dihydrate, $\mathrm{CaHPO}_{4}, \mathrm{Ca}_{3}\left(\mathrm{PO}_{4}\right)_{2}$, octacalcium phosphate, and hydroxyapatite. These compounds form insoluble $\mathrm{CaHPO}_{4}$ and $\mathrm{Ca}_{3}\left(\mathrm{PO}_{4}\right)_{2}$ under alkaline conditions. Apart from chemical adsorption effects, the porous

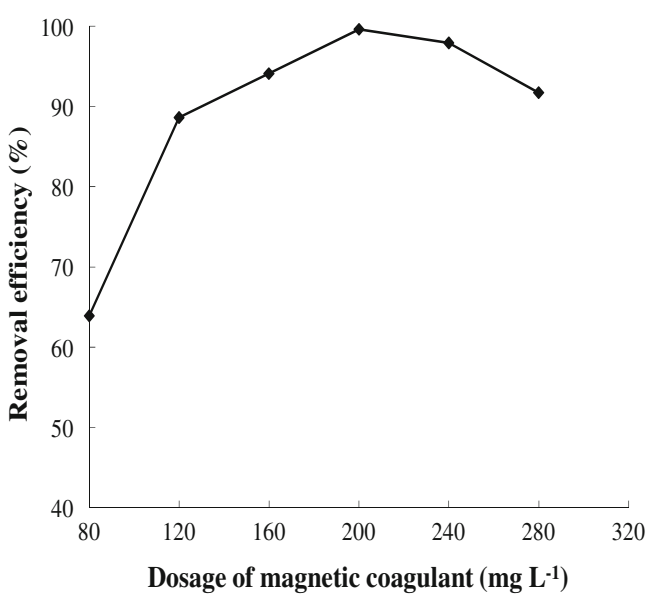

Fig. 2 Effect of dosage of magnetic coagulant on turbidity 


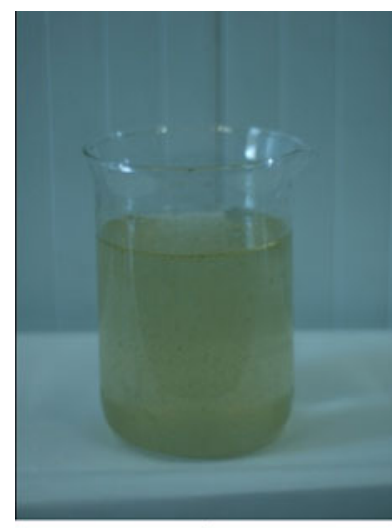

A

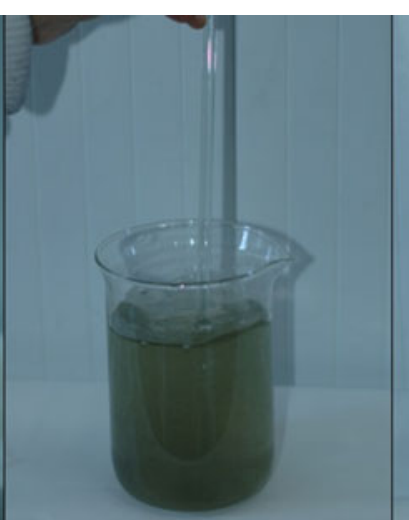

B

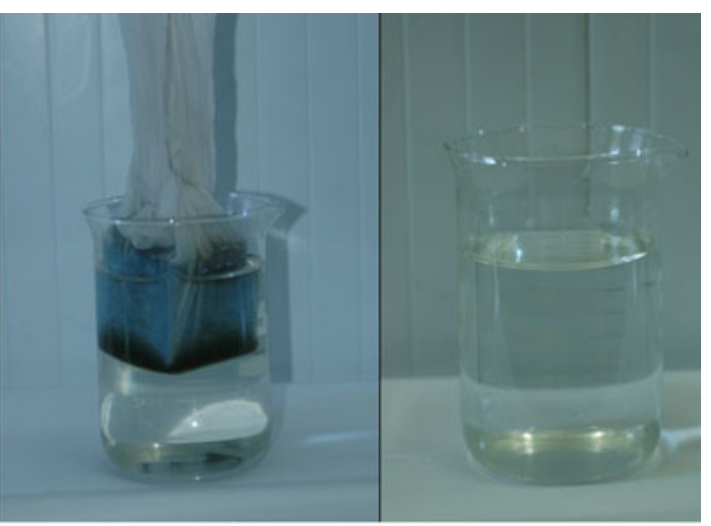

C

D

Fig. 3 Treating process of algal suspension. a Algal suspension. b Adding magnetic coagulants. c Separating flocs from water. d Treated water

nature (i.e., large surface area) of modified fly ash also has physical adsorption effects on P removal (Yao et al. 2009).

\section{Evaluation of algal removal effects}

To verify the purification effects of the magnetic coagulant, new algae are introduced to the processed sample treated with magnetic coagulant (Fig. 6). The new solution is cultured in a light incubator at $25-28^{\circ} \mathrm{C}$ with a light intensity of 2,200 lx and dark cycle ratio of 12:12 h. The solution was mechanically shaken three to four times during daytime every day. All algal cells were observed to be dead in the precipitate after a week (Fig. 6c). The new solution obtained after magnetic coagulants treatment has conditions that cannot allow algae to survive. Thus, the possibility of bloom reoccurrence is close to zero.

The results of the four control experiments indicate that after adding P-free source M-11 medium (Fig. 6d) or M-11 medium without an $\mathrm{N}$ or P source (Fig. $6 \mathrm{~g}$ ) to the processed solution, new algae are introduced. Under the same incubation conditions, all algal cells die in the precipitate after a week (Fig. 6d, g). After introducing N-free source M-11

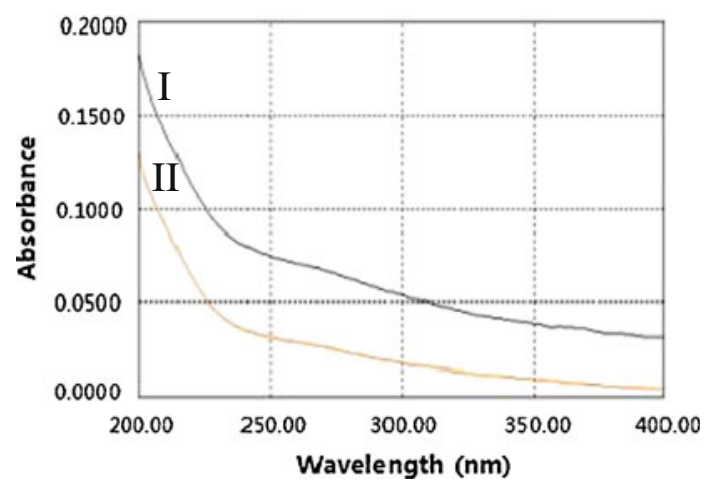

Fig. 4 Samples' spectral scanning curves of ultraviolet band. I Control (untreated). II Control $+200 \mathrm{mg} \mathrm{L}^{-1}$ magnetic coagulants (treated) medium (Fig. 6e) or M-11 medium with $\mathrm{N}$ and $\mathrm{P}$ sources (Fig. 6f), algal cells grow vigorously after a week (Fig. 6e, f). Thus, $\mathrm{P}$ is a restrictive factor on algal cell growth and is a key element in bloom inhibition (Havens 2003). P reduction in a water body is a crucial process for treating eutrophication. One of the biggest advantages of a magnetic coagulant is its significant effect in $\mathrm{P}$ reduction; $\mathrm{M}-11$ medium composition: $\mathrm{NaNO}_{3} 100 \mathrm{mg} \mathrm{L}{ }^{-1}, \mathrm{~K}_{2} \mathrm{HPO}_{4} 10 \mathrm{mg} \mathrm{L}^{-1}$, $\mathrm{MgSO}_{4} \cdot 7 \mathrm{H}_{2} \mathrm{O} 75 \mathrm{mg} \mathrm{L}^{-1}, \mathrm{CaCl}_{2} \cdot 2 \mathrm{H}_{2} \mathrm{O} 40 \mathrm{mg} \mathrm{L}^{-1}$, $\mathrm{Na}_{2} \mathrm{CO}_{3} 20 \mathrm{mg} \mathrm{L}{ }^{-1}$, Fe $\cdot$ citrate $\cdot x \mathrm{H}_{2} \mathrm{O} 6 \mathrm{mg} \mathrm{L}^{-1}$, $\mathrm{Na}_{2}$ EDTA $2 \mathrm{H}_{2} \mathrm{O} 1 \mathrm{mg} \mathrm{L}{ }^{-1}, \mathrm{pH}$ 8.0, where $\mathrm{NaNO}_{3}$ as $\mathrm{N}$ source and $\mathrm{K}_{2} \mathrm{HPO}_{4}$ as $\mathrm{P}$ source.

Preliminary study on mechanism

Pollutants in algal solutions mainly exist in the form of colloids. Colloids have high surface free energy, efficient adsorption capacity, and Brownian motion characteristics. Thus, particles have more chances to collide, adhere, and aggregate into larger particles. However, colloids of the same kind carry identical electric charges. The electrostatic repulsion among colloids prevents them to be close to one

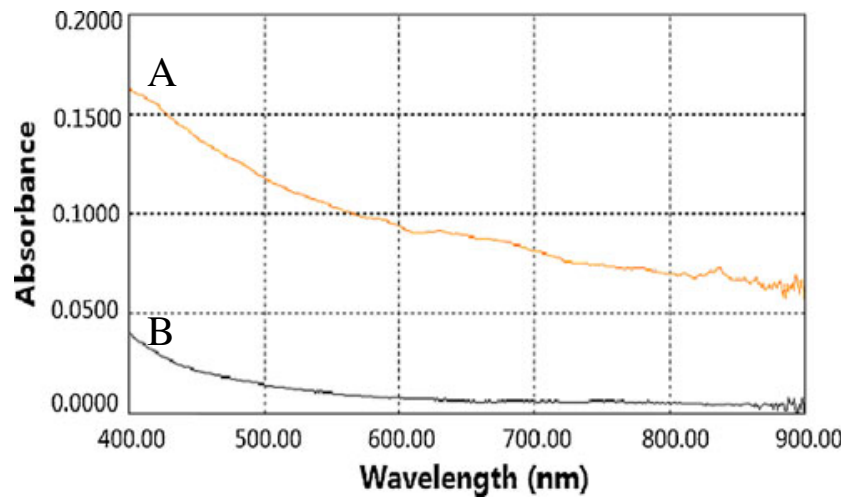

Fig. 5 Samples' spectral scanning curves of visible band. $a$ Control. $b$ Control $+200 \mathrm{mg} \mathrm{L}^{-1}$ magnetic coagulants 

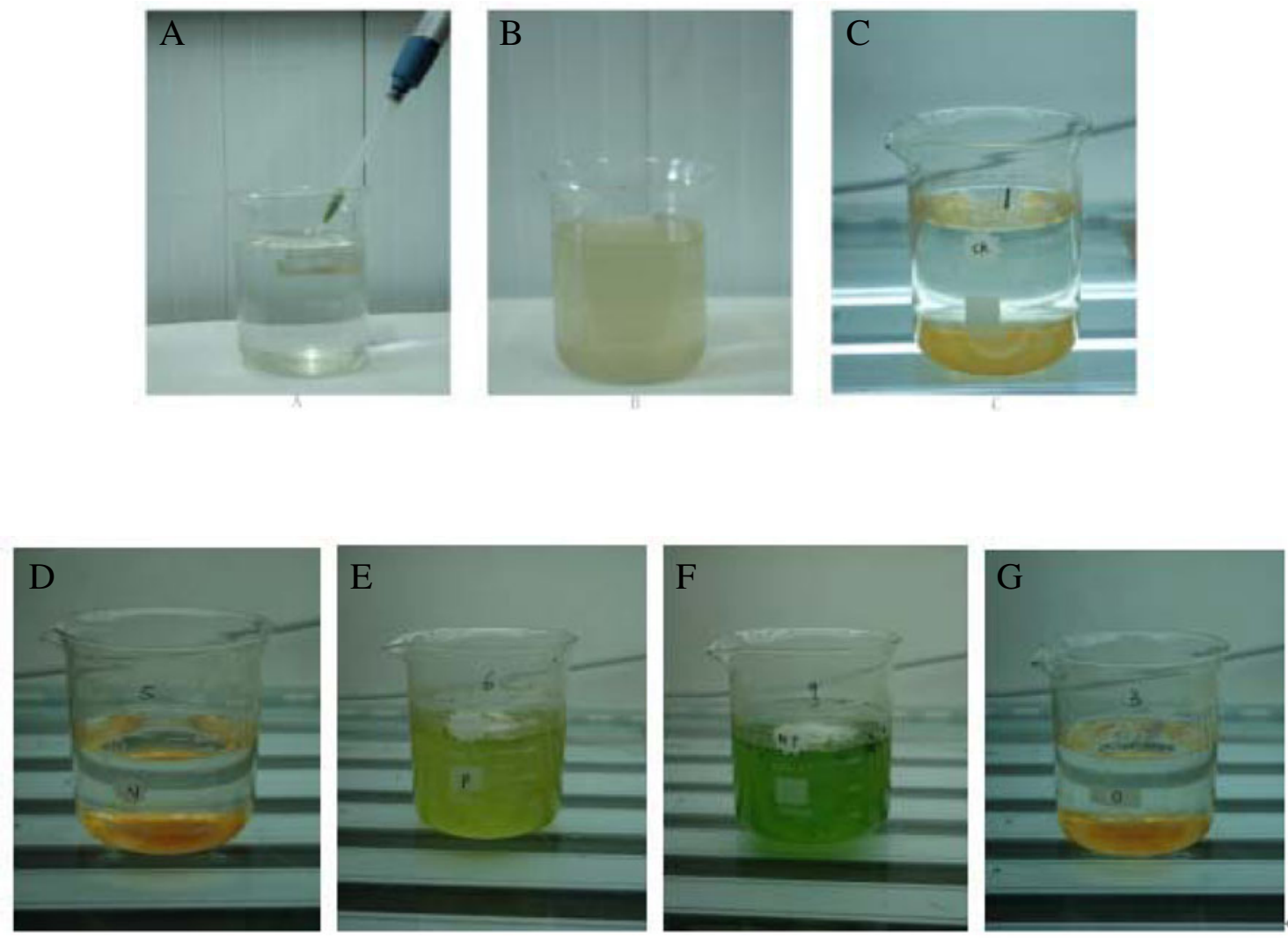

Fig. 6 Survivability experiment of new algae in treated water. a Introducing new algae into treated water. b Cultivation of new algal suspension. c Algae died and precipitated 1 week later. d A week after

adding $\mathrm{N}$ source. e A week after adding $\mathrm{P}$ source. $\mathbf{f}$ A week after adding $\mathrm{N}$ and $\mathrm{P}$ sources. $\mathrm{g}$ A week after adding non- $\mathrm{N}$ or $\mathrm{P}$ source

On the other hand, magnetite provides an adsorption surface for weak magnetic substances such as algae and become the nuclei of floc cohesion. The weak magnetic fields generated by magnetite strongly appeal to charged colloidal particles. Magnetic seeds and flocs can quickly combine closely to form magnetic flocs (Fig. 7) and induce magnetism under because it fully promotes the synergies of coagulation (modified fly ash) and magnetic separation (magnetite).

Modified fly ash has both physical adsorption and chemical coagulation effects. First, modified fly ash can release large amounts of $\mathrm{Al}^{3+}$ and $\mathrm{Fe}^{3+}$ ions to reduce the $\zeta$ potential of suspended colloidal particles to destabilize them. Fly ash particles after acid treatment also form numerous grooves and holes on the surface to adsorb destabilized colloids. Second, modified fly ash contains coagulation substances, including ferric chloride, aluminum chloride, silicic acid, etc. Silicic acid intensively captures suspended particles to form adsorption bridges favorable to coagulation. The hydrolytic substances of modified fly ash also hydrolyze to form complex polynuclei and polycondense constantly to form a polymer gradually. With continuous polycondensation, polymer charge increases, which favors suspended colloidal adsorption (Sun et al. 2011).

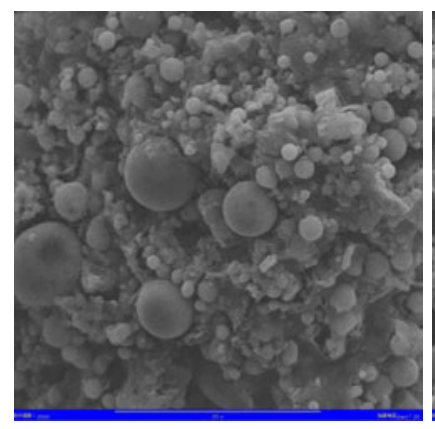

$\mathrm{a}-\times 2000,30 \mu \mathrm{m}$

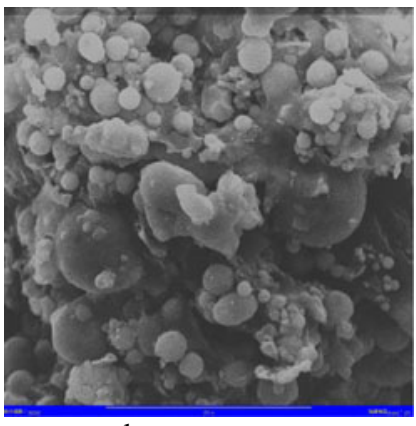

$\mathrm{b}-\times 3000,20 \mu \mathrm{m}$

Fig. 7 SEM images of magnetic flocs. a $\times 2,000,30 \mu \mathrm{m} . \mathbf{b} \times 3,000$, $20 \mu \mathrm{m}$ 
the magnetic field. Eventually, the magnetic enrichment results in the effective separation of algae from water.

\section{Conclusions}

The magnetic-coagulation separation method uses selfmade magnetic coagulants to remove algae from water bodies rapidly and efficiently. The method has the advantage of transforming waste into something valuable for water treatment. The new method has significantly reduced production cost and confers substantial environmental, economic, and social benefits. This study discusses a new method to deal with algal blooms and mitigate eutrophication of freshwater. The results provide reference and directions for future pilot and production scale-ups.

The optimum magnetic coagulant dosage is $200 \mathrm{mg} \mathrm{L}^{-1}$. The use of a magnet $(0.5 \mathrm{~T})$ to separate magnetic flocs can achieve $100 \% \mathrm{Chl}-a$ removal rate. The turbidity, COD, total $\mathrm{N}$, and total $\mathrm{P}$ are decreased by $99.6,93,91$, and $94 \%$, respectively. The treated suspension greatly reduces UVVisible light absorption and disables the survival of algal cells.

A preliminary study on the mechanism indicates that modified fly ash exerts both physical adsorption and chemical coagulation effects on algal cells. Magnetite becomes the nuclei of floc cohesion and enables the separation of algae from water under the action of magnet.

Acknowledgments This work was financially supported by the National Natural Science Foundation of China (grant no. 21077027), Postdoctoral Science Foundation of China, and Centre National de la Recherche Scientifique.

\section{References}

Anderson DM (1997) Turning back the harmful red tide. Nature 388 (6642):513-514

Beth B (1998) Washington watch: harmful algal blooms. Bioscience 48 (1):12

Codd GA (2000) Cyanobacterial toxins, the perception of water quality, and the prioritisation of eutrophication control. Ecol Eng 16 (1):51-60

Datta S, Jana BB (1998) Control of bloom in a tropical lake: grazing efficiency of some herbivorous fishes. J Fish Biol 53(1):12-24

Divakaran R, Pillai VNS (2002) Flocculation of algae using chitosan. J Appl Phycol 14(5):419-422

Gao SS, Yang JX, Tian JY, Ma F, Tu G, Du MA (2010) Electrocoagulation-flotation process for algae removal. J Hazard Mater 177(1-3):336-343

Ghernaout B, Ghernaout D, Saiba A (2010) Algae and cyanotoxins removal by coagulation/flocculation: a review. Desalin Water Treat 20(1-3): 133-143

Havens KE (2003) Phosphorus-algal bloom relationships in large lakes of South Florida: implications for establishing nutrient criteria. Lake Res Manag 19(3):222-228
Hejzlar J, Dolejs P, Komarkova J, Seda J, Simek K, Vyhnalek V (1998) Effect of biomanipulation on the structuring of the planktonic food web and water treatability by coagulation. Water Sci Technol 37:105-112

Hoehn RC, Barnes DB, Thompson BC, Randall CW, Grizzard TJ, Shaffer PTB (1990) Algae as sources of Trihalomethane precursors. J Am Water Works Assoc 82(6):344-350

Lam AKY, Prepas EE, Spink D, Hrudey SE (1995) Chemical control of hepatotoxic phytoplankton blooms: implications for human health. Water Res 29(8):1845-1854

Liu D, LI FT, Zhang BR (2009) Removal of algal blooms in freshwater using magnetic polymer. Water Sci Technol 59(6):1085-1091

Mackenzie D (1999) Alien invaders-FOCUS exotic species threaten the fragile balance of the Baltic. But it may not be too late to save the sea and its fishing industry. New Sci 162(2183):18-19

Nagasaki K, Tarutani K, Yamaguchi M (1999) Growth characteristics of Heterosigma akashiwo virus and its possible use as a microbiological agent for red tide control. Appl Environ Microb 65:898-902

Pan G, Zhang MM, Chen H, Zou H, Yan H (2006) Removal of cyanobacterial blooms in Taihu Lake using local soils I. Equilibrium and kinetic screening on the flocculation of Microcystis aeruginosa using commercially available clays and minerals. Environ Pollut 141:195-200

Pengthamkeerati P, Satapanajaru T, Chularuengoaksorn P (2008) Chemical modification of coal fly ash for the removal of phosphate from aqueous solution. Fuel 87(12):2469-2476

Pierce RH, Henry MS, Higham CJ, Bluma P, Sengco MR, Anderson DM (2004) Removal of harmful algal cells (Karenia brevis) and toxins from seawater culture by clay flocculation. Harmful Algae 3:141-148

Pouria S, Andrade AD, Barbosa J, Cavalcanti RL, Barreto VTS, Ward CJ, Preiser W, Poon GK, Neild GH, Codd GA (1998) Fatal microcystin intoxication in haemodialysis unit in Caruaru, Brazil. Lancet 352(9121):21-26

Rigby G (2000) From ballast to bouillabaisse. Science 289(5477):241242

Ruiz GM, Rawlings TK, Dobbs FC, Drake LA, Mullady T, Huq A, Colwell RR (2000) Global spread of microorganisms by shipsballast water discharged from vessels harbours a cocktail of potential pathogens. Nature 408(6808):49-50

Sengco MR, Anderson DM (2004) Controlling harmful algal blooms through clay flocculation. J Eukaryot Microbiol 51:169-172

State Environmental Protection Administration of China (2002) Standard methods for the examination of water and wastewater, 4th edn. China Environmental Science Press, Beijing

Sun T, Sun CH, Zhu GL, Miao XJ, Wu CC, Lv SB, Li WJ (2011) Preparation and coagulation performance of poly-ferric-aluminumsilicate-sulfate from fly ash. Desalination 268(1-3):270-275

Vasconcelos VM, Pereira E (2001) Cyanobacteria diversity and toxicity in a wastewater treatment plant (Portugal). Water Res 35 (5):1354-1357

Yao SH, Li JY, Shi ZL (2009) Phosphate ion removal from aqueous solution using an iron oxide-coated fly ash adsorbent. Adsorpt Sci Technol 27(6):603-614

Yu YX, Wu GQ, Meng XT (1990) Manual for microorganism test in environmental engineering. China Environmental Science Press, Beijing

Zhang YJ, Zhao XL, Li XX, Liu C, Zhu LL (2010) Performance of PAC/PDM composite coagulants for removal of algae from Lake Taihu waters in summer. Water Sci Technol 62(2):330-339

Zou H, Pan G, Chen H, Yuan XZ (2006) Removal of cyanobacterial blooms in Taihu Lake using local soils II. Effective removal of Microcystis aeruginosa using local soils and sediments modified by chitosan. Environ Pollut 141:201-205 